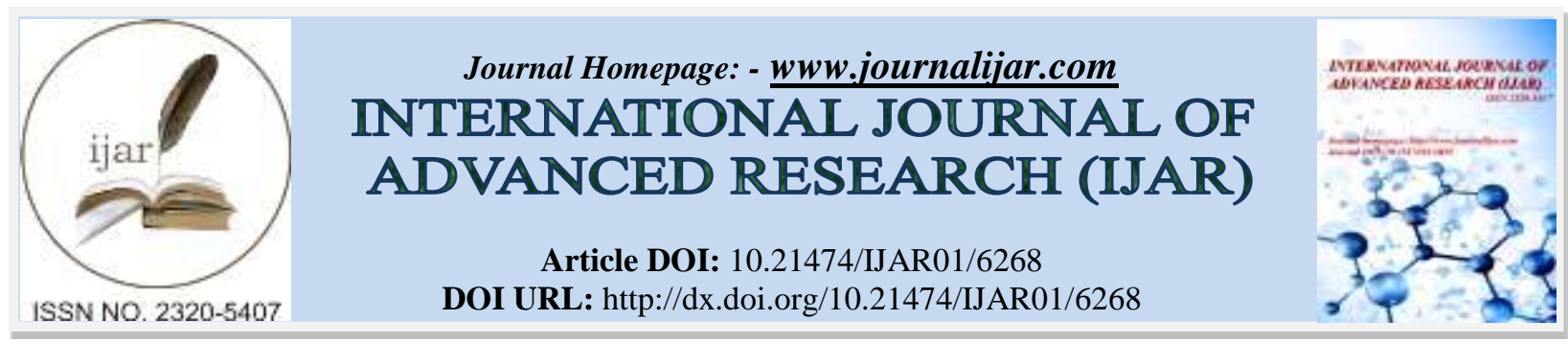

RESEARCH ARTICLE

\title{
IRANIAN CINEMA: PRE-REVOLUTION AND POST-REVELOUTION.
}

\section{Majid Sarsangi ${ }^{1}$ and Hamed Soleimanzadeh ${ }^{2}$.}

1. Department of Arts, School of Performing Arts and Music, College of Fine Arts, Tehran University.

2. $\mathrm{PhD}$ art research, NazarInstitute of Art, Architecture and Urbanism in Tehran.

\section{Manuscript Info}

Manuscript History

Received: 10 November 2017

Final Accepted: 12 December 2017

Published: January 2018

Key words:-

Iran, cinema, pre- revolution, postrevolution, New wave.

\begin{abstract}
The Cinema of Iran or Cinema of Persia refers to the cinema and film industries in Iran which produce a variety of commercial films annually. Iranian art films have garnered international fame and now enjoy a global following.

Iran has been lauded as one of the best exporters of cinema in the 1990s. Some critics now rank Iran as the world's most important national cinema, artistically, with a significance that invites comparison to Italian neorealism and similar movements in past decades. A range of international film festivals have honored Iranian cinema in the last twenty years. World-renowned filmmakers along with many film critics from around the world, have praised Iranian cinema as one of the world's most important artistic cinemas.
\end{abstract}

Copy Right, IJAR, 2018,. All rights reserved.

\section{Introduction:-}

The earliest examples of visual representations in Iranian history may be traced back to the bas-reliefs in Persepolis (c. 500 B. C.). Bas relief is a method of sculpting which entails carving or etching away the surface of a flat piece of stone or metal. Persepolis was the ritual center of the ancient kingdom of Achaemenids and the figures at Persepolis remain bound by the rules of grammar and syntax of visual language.

Iranian visual arts maybe said to have peaked about a thousand years later during the Sassanian reign. A bas-relief from this period in Taq Bostan (western Iran) depicts a complex hunting scene. Similar works from the period have been found to articulate movements and actions in a highly sophisticated manner. It is even possible to see the progenitor of the cinema close-up: a wounded wild pig escaping from the hunting ground, among these works of art. After the conversion from Zoroastrianism to Islam - a religion in which visual symbols were avoided — Persian art continued its visual practices. Persian miniatures provide great examples of such continued attempts. The deliberate lack of perspective in Persian miniature enabled the artist to have different plots and sub-plots within the same image space. A very popular form of such art was Pardeh Khani. Another type of art in the same category was Naqqali.

Popular dramatic performance arts in Iran, before the advent of cinema, include Marionette, Saye-bazi (shadow plays), Rouhozi (comical acts), and Ta'zieh.

The background to the advent of Iranian cinema should be on this historical background.

Corresponding Author:- Majid Sarsangi.

Address:- Department of Arts, School of Performing Arts and Music, College of Fine Arts, Tehran 


\section{Early Iranian cinema:-}

Cinema was only five years old when it came to Persia at the beginning of the 20th century. The first Persian filmmaker was Mirza Ebrahim Khan Akkas Bashi, the official photographer of Muzaffar al-Din Shah, the Shah of Persia from 1896-1907. After a visit to Paris in July 1900, Akkas Bashi obtained a camera and filmed the Shah's visit to Europe upon the Shah's orders. He is said to have filmed the Shah's private and religious ceremonies, but no copies of such films exist today. A few years after Akkas Bashi started photography, Khan Baba Motazedi, another pioneer in Iranian motion picture photography emerged. He shot a considerable amount of newsreel footage during the reign of Qajar to the Pahlavi dynasty. The first public screening took place in Tehran in 1904, presented by Mirza Ebrahim Khan Sahaf Bashi. He arranged the screening in the back of his antique shop. In 1905, Sahaf Bashi opened the first movie theater in Cheragh Gaz Avenue in the national capital. In 1909, with fall of the Mohammad Ali Shah Qajar heir of Mozaffar ad-Din Shah Qajar and the success of the constitutionalists, Russi Khan lost his support. Consequently, his film theatre and photography studios were destroyed by the public. Soon after, other cinema theatres in Tehran closed down. Movie theatres sprang up again in 1912 with the help of Ardeshir Khan an Armenian -Iranian. In 1925, Ovanes Ohanian, decided to establish the first film school in Iran. In 1904, Mirza Ebrahim Khan Sahhafbashi opened the first movie theater in Tehran. The cinematographic camera was introduced to Iran in 1929, as yet another tool of modernization. After Mirza Ebrahim Khan, several others like Russi Khan, Ardeshir Khan, and Ali Vakili tried to establish new movie theaters in Tehran. Until the early 1930s, there were little more than 15 theatres in Tehran and 11 in other provinces. In 1925, Ovanes Ohanian, decided to establish the first film school in Iran. Within five years he managed to run the first session of the school under the name Parvareshgahe Artistiye Cinema.

In 1930 the first Iranian silent film was made by Professor Ovanes Ohanian called Abi and Rabi. In 1933 he made his second film titled Haji Agha. Later that year, Abdolhossein Sepanta made the first Iranian sound film, entitled Lor Girl was released 1933 in two Tehran cinemas, Mayak and Sepah. The story of the film was based on a comparison between the state of security in Iran at the end of the Qajar dynasty and during Reza Shah period. Sepanta would go on to direct movies such as Ferdowsi (the life story of the most celebrated epic poet of Iran), Shirin and Farhad (a classic Iranian love story), and Black Eyes (the story of Nader Shah's invasion of India). In 1937, he directed Laili and Majnoon, an Eastern love story similar to the English story of Romeo and Juliet.(Umid,1995:110)

The present day Iranian film industry owes much of its progress to two industrious personalities, Esmail Koushan and Farrokh Ghaffari. By establishing the first National Iranian Film Society in 1949 at the Iran Bastan Museum and organizing the first Film Week during which English films were exhibited, Ghaffari laid the foundation for alternative and non-commercial films in Iran.

Early Persian directors like Abdolhossein Sepanta and Esmail Koushan took advantage of the richness of Persian literature and ancient Persian mythology. In their work, they emphasized ethics and humanity.

\section{Pre-revolutionary cinema, 1950s-70s:-}

The 1960s was a significant decade for Iranian cinema, with 25 commercial films produced annually on average throughout the early ' $60 \mathrm{~s}$, increasing to 65 by the end of the decade. The majority of production focused on melodrama and thrillers. From 1937 till 1947 because of the world economic conditions and then the involvement in World War Two, the motion picture industry in Iran did not produce a single film, but the flow of foreign film to Iran did not stop. In 1947, Esmail Koushan, With the help of some of his colleagues, he established Mitra Films (1947), the first real film company in Tehran, Iran. Through their persistence, local feature film production was born and survived. The movie that really boost the economy of Iranian cinema and initiated a new genre was Ganj-e Qarun (Croesus Treasure), made in 1965 by Syamak Yasami. Four years later Masoud Kimiai made Kaiser. With Kaiser (Qeysar), Kimiai depicted the ethics and morals of the romanticized poor working class of the Ganj-e-Qarun genre through his main protagonist, the titular Qeysar. But Kimiay's film generated another genre in Iranian popular cinema: the tragic action drama.

With the screening of the films Kaiser and The Cow, directed by Masoud Kimiai and Darius Mehrjui respectively in 1969, alternative film established their status in the film industry.By 1970 Iranian cinema entered into its mature stage. The College of Dramatic Arts, instituted in 1963, produced its first graduates at the decade's beginning. Many progressive film co-ops and associations came into existence; and there were a few regular film festivals taking place in the country. Attempts to organize a film festival that had begun in 1954 within the framework of the 
Golrizan Festival, bore fruits in the form of the Sepas Film Festival in 1969. The endeavors of Ali Mortazavi also resulted in the formation of the Tehran International Film Festival in 1973. From 1950 to the mid-1960 the Iranian film industry grew rapidly. Many studios were established as well as others that entered the Cycle of the film industry independently. There were 324 films produced during this period 1950 for 1965 . By 1965 there were 72 movie theatres in Tehran and 192 in other Provinces. (Dabashi,2001:112)

Ebrahim Golestan in 1965 directed by films of interest Brick and Mirror 1965. Bahram Beyzai is the director of one of the ground-breaking films of the Iranian New wave, 1972 Ragbar (Downpour). Sohrab Shahid-Saless is auteur director who embodied his original style in his 1975 film Still Life. Abbas Kiarostami is now a well known director of the 1990s who directed one of the last films that screened before the revolution in 1978, Gozaresh (The Report). The document also Forough Farrokhzad by making The House Is Black in 1962 the promoted new style Documentatio.

\section{Post-revolutionary cinema:-}

In the early 1970s, a New Iranian Cinema emerged (cinema motefävet). In 1982, the annual Fajr Film Festival financed films. The Farabi Cinema Foundation then stepped in to try and reassemble the disorganized cinema. The following year, the government began to provide financial aid. This change in regime encouraged a whole new generation of filmmakers, which included female directors as well. With this, the focus shifted to children overcoming obstacles: true stories, lyrical, mystical drama, real-life problems, documentary footage, etc.

Post-revolutionary Iranian cinema has been celebrated in many international forums and festivals for its distinct style, themes, authors, idea of nationhood, and cultural references. Starting With Viva... by Khosrow Sinai and followed by many excellent Iranian directors who emerged in the last few decades, such as Abbas Kiarostami and Jafar Panahi. Abbas, who some critics regard as one of the few great directors in the history of cinema, planted Iran firmly on the map of world cinema when Abbas won the Palme d'Or at the Cannes Film Festival for Taste of Cherry in 1997.

The continuous presence of Iranian films in prestigious international festivals such as the Cannes Film Festival, the Venice Film Festival, and the Berlin Film Festival attracted world attention to Iranian masterpieces .. In 2006, six Iranian films, of six different styles, represented Iranian cinema at the Berlin Film Festival. Critics considered this a remarkable event in the history of Iranian cinema. (Sadr,2006:147)

An important step was taken in 1998 when the Iranian government began to fund ethnic cinema. Since then Iranian Kurdistan has seen the rise of numerous filmmakers. In particular the film industry got momentum in Iranian Kurdistan and the region has seen the emergence of filmmakers such as Bahman Ghobadi, actually the entire Ghobadi family, Ali-Reza Rezai, Khosret Ressoul and many other younger filmmakers.

There is also movie-documentary production, often critical of the society in the name of the Islamic revolution ideal, like the films directed by Mohammedreza Eslamloo."Tranquility in the Presence of Others" (Aramesh dar Hozur Deegaran, 1973) directed by Nasser Taghvai has been rated by some critics as the best Iranian film of all times.

By the year 2001 the number of features produced in Iran rose to 87 (from 28, which is the number of films that were produced in 1980, after the fall of the Shah). The most popular genres were melodramas and historical pageants which seldom went to festivals. In 1997, the newly elected president, Mohammed Khatemi, would eventually come to play a role in helping filmmakers achieve a certain degree of artistic freedom.(Ibid:200)

\section{Commercial cinema in Iran:-}

The internationally award-winning cinema of Iran is quite different from the domestically oriented films. The latter caters to an entirely different audience, which is largely under the age of 25. This commercial Iranian cinema genre is largely unknown in the West, as the films are targeted at local audiences. There are Three categories of this type of film:

Films before the revolution: Lor Girl, A Party in Hell, Qeysar, Dar Emtedade Shab, Amir Arsalan, and Ganj-e Qarun.

Films about the victory of the Iranian Revolution of 1979 and the ensuing Iran-Iraq war and Action filled with strong religious and national motifs: Eagles, Barzakhiha, The Viper, Dadshah, Boycott, Duel, Taraj, 
Ekhrajiha, The Glass Agency, Kani Manga, Ofogh, Bashu, the Little Stranger, Leily Ba Man Ast, M as in Mother and The Night Bus.

Formulaic films starring popular actors: With 130 Iranian films looking for a screening each year, cinema managers tend to prefer crowd-pleasing comedies, romantic melodramas, and family comedies over the other genres. The Lizard, The Blue-Veiled, Ghermez, Leila, Outsiders, Char Changooli, Kolah Ghermezi and Pesar Khaleh, Kolah Ghermezi and Bache Naneh, Actor, Ejareh-Nesheenha, Shokaran, Dayere Zangi, Aquarium, Cease Fire, No Men Allowed, The Changed Man, Charlatan, The Kingdom of Solomon, Guidance Patrol, Killing Mad Dogs, A Separation and Hush! Girls Don't Scream were among the post-revolutionary films that gained the highest box office records.(Dabashi,2001:139)

During the war years, crime thrillers such as Senator, The Eagles, Boycott, The Tenants, and Kani Manga occupied the first position on the sales charts.

Simultaneous, Numerous Western commercial films such as Jaws, The Illusionist, Passion of the Christ, House of Sand and Fog, Sky Captain and the World of Tomorrow, Sherlock Holmes, Alpha and Omega, Scarface, Casino Royale, The Mechanic, and The Aviator have been screened in Iranian cinemas and Iranian film festivals since the revolution. Despite great pride in the country's more than 100-year film history, Western cinema is enormously popular among Iran's young people, and practically every recent Hollywood film is available on CD, DVD, or video. State television has also broadcast more Western movies - partly because millions of Iranians have been switching to the use of banned satellite television equipment.

There is no particular love of Arab cinema but Indian cinema is relatively popular among the Iranian masses. 6 to 8 Bollywood films make it to Iranian movie theaters each year.

\section{Iranian New Wave films:-}

refers to a new movement in Iranian cinema. It started in 1964 with Hajir Darioush's second film Serpent's Skin, which was based on D.H. Lawrence's Lady Chatterley's Lover featuring Fakhri Khorvash and Jamshid Mashayekhi. Darioush's two important early social documentaries But Problems Arose in 1965, dealing with the cultural alienation of the Iranian youth, and Face 75, a critical look at the westernization of the rural culture, which was a prizewinner at the 1965 Berlin Film Festival, were also contributing significantly to the establishment of the New Wave. In 1969, after the release of The Cow directed by Darius Mehrjui followed by Masoud Kimiai's Qeysar, and Nasser Taqvai's Calm in Front of Others, the New Wave became well established as a prominent cultural, dynamic and intellectual trend. The Iranian viewer became discriminating, encouraging the new trend to prosper and develop. In the 1960s, there were 'New Wave' movements in the cinema of numerous countries. The pioneers of the Iranian New Wave were directors like Forough Farrokhzad, Sohrab Shahid Saless, Bahram Beizai, and Parviz Kimiavi. They made innovative art films with highly political and philosophical tones and poetic language. Subsequent films of this type have become known as the New Iranian cinema to distinguish them from their earlier roots. The most notable figures of the Iranian New Wave are Abbas Kiarostami, Jafar Panahi, Majid Majidi, Bahram Beizai, Darius Mehrjui, Mohsen Makhmalbaf, Khosrow Sinai, Sohrab Shahid-Saless, Parviz Kimiavi, Samira Makhmalbaf, Amir Naderi, and Abolfazl Jalili. (Sadr,2006:152)

The factors leading to the rise of the New Wave in Iran were, in part, due to the intellectual and political movements of the time. A romantic climate was developing after the 19 August 1953 coup in the sphere of arts. Alongside this, a socially committed literature took shape in the 1950s and reached a peak in the 1960s, which may consider as the golden era of contemporary Persian literature.

Features of New Wave Iranian film, in particular the works of legendary Abbas Kiarostami, can be classified as postmodern.

Iranian New Wave films shared some characteristics with the European art films of the period, in particular Italian Neorealism. However, in her article 'Real Fictions', Rose Issa argues that Iranian films have a distinctively Iranian cinematic language "that champions the poetry in everyday life and the ordinary person by blurring the boundaries between fiction and reality, feature film with documentary." She also argues that this unique approach has inspired European cinema directors to emulate this style, citing Michael Winterbottom's award winning In This World (2002) as an homage to contemporary Iranian cinema. Issa claims that "This new, humanistic aesthetic language, 
determined by the film-makers'individual and national identity, rather than the forces of globalism, has a strong creative dialogue not only on home ground but with audiences around the world.

In his book Close Up: Iranian Cinema, Past, Present, Future (2001) Hamid Dabashi describes modern Iranian cinema and the phenomenon of [Iranian] national cinema as a form of cultural modernity. According to Dabashi, "the visual possibility of seeing the historical person (as opposed to the eternal Qur'anic man) on screen is arguably the single most important event allowing Iranians access to modernity."(Dabashi,2001:36)

While Beyzai and Taghvai represent the first generation and Karim-Masihi and Kiarostami represent the second generation of New wave filmmakers, the third generation is represented by Rafi Pitts, Bahman Ghobadi, Maziar Miri, Asghar Farhadi, Mani Haghighi, and Babak Payami, along with newly emerged filmmakers such as Kiumars Pourahmad, Majid Majidi, Kiarash Anvari, Maziar Bahari, Sadaf Foroughi, Saman Salur, Abdolreza Kahani, and Mona Zandi-Haqiqi.

\section{Iranian popular art films:-}

Parallel to the Iranian New Wave, with its neorealist and minimalist art cinema, there exists a so-called "popular art cinema" in Iran. Filmmakers who belong to this circle make films with a broader range of audience than the narrow spectrum of highly educated people who admire the New Wave, but believe that their movies are also artistically sound. Filmmakers such as Nasser Taghvaee and Ali Hatami are the best examples of this cinematic movement (some of these filmmakers also make new wave films e.g. Mum's Guest by Darius Mehrjui). The Demon and the Bald Hassan, Adam and Eve, The Fisherman's Story, City of Oranges, and Talisman are some of Hatami's works.

\section{Iranian war films:-}

War cinema in Iran was born simultaneously with the beginning of Iran-Iraq War. However, it took many years until it found its way and identity by defining characteristics of Iranian war cinema. Shows the most poematic view on the Iran Iraq war and still after years, is one of the leading films about this historical event from a humanistic aspect, although unlike other Iranian war cinema which are fully supported by the Iranian government this film was made with numerous difficulties. In the past decades, the Iranian film industry has produced many war films. In the Iranian war film genre, war has often been portrayed as glorious and "holy", bringing out the good in the protagonist and pandering to nationalist sentiments with propagandistic messaging. Tears of Cold and Duel were two films that have gone beyond the traditional view of war. Many renowned directors were involved in developing Iranian war cinema.(Tallattof,2013:82)

Other films famous and popular Iran Iraq War: Goodbye Life directed by Ensieh Shah-Hosseini, Heeva, Mazrae-ye pedari and Safar be Chazabeh directed by Rasoul Mollagholipour, Kirkuk Operation, Hoor on Fire and Kani Manga directed by Seifollah Dad. Che, Az Karkheh ta Rhein, Mohajer and The Red Ribbon directed by Ebrahim Hatamikia. Big Drum Under Left Foot directed by Kazem Masoumi. Gilaneh directed by Rakhshan Bani-E'temad. The Day Third directed by Mohammad Hossein Latifi. The Reward of Silence directed by Maziar Miri. Sizdah 59 directed by Saman Salur. The Queen directed by Mohammad Ali Bashe Ahangar. Mardi shabih-e baran directed by Saeed Soheili. Bashu, the Little Stranger directed by Bahram Beyzai. Snake Fang directed by Masoud Kimiai and Hoor dar Atash directed by Azizollah Hamidnezhad.

\section{Conclusion:-}

In recent years, post-revolutionary Iranian cinema has been praised in many international forums. What has attracted international audiences to this national cinema is its distinct style, themes, authors, idea of nationhood, and manifestation of culture. In my essay, I contextualized the emergence of this new cinema by providing a brief historical background of Iranian national cinema, with an emphasis on the foundations of filmic art in that region and the brief history of pre-revolutionary iranian cinema. 


\section{Refrences:-}

1. Umid, Jamal, Tarikh-i sinima-yi Iran : 1279-1357 / Jamal Umid = [The history of Iranian cinema] : [1900-1978] / [Jamal Omid] 1175 pages. Illustrated. Press:Teheran Rawzanah. Year:1374[1995]. Language:Persian.

2. Displaced Allegories: Post-Revolutionary Iranian Cinema (Duke University Press, 2008). ISBN 978-0-82234275-5

3. Hamid Dabashi, Close Up: Iranian Cinema, Past, Present, and Future, 320 p. (Verso, London, 2001). ISBN 185984-332-8

4. Hamid Dabashi, Masters \& Masterpieces of Iranian Cinema, 451 p. (Mage Publishers, Washington, D.C., 2007) ISBN 0-934211-85-X

5. Gönül Dönmez-Colin, Cinemas of the Other, Intellect (April, 2006) ISBN 978-1-84150-143-7

6. Hamid Reza Sadr, Iranian Cinema: A Political History, I.B.Tauris (2006). ISBN 978-1-84511-Najmeh Khalili Mahani, Women of Iranian Popular Cinema: Projection of Progress, Offscreen, Vol. 10, Issue 7, July 31, 2006

7. Hester, Elizabeth J. "Cinema in Iran: A Selective Annotated Bibliography of Dissertations and Theses" ISBN 978-1493505494.

8. K. Talattof \& A.A. Seyed-Gohrab (eds.), Conflict and Development in Iranian Film (Leiden: Leiden University Press, 2013). ISBN 978-908-72-8169-4

9. Keddie, Nikki R. Religion and Rebellion in Iran 1891-1892. London: Cass, 1966).

10. Lenczowski, George. Iran Under the Pahlavis. Stanford, California: Hoover Institution, 1978. 